\title{
Rethinking Religion in the Context of Ethnicity and Wellbeing
}

\author{
Aliakbar Jafari \\ Department of Marketing, University of Strathclyde, UK
}

\section{Ayla Özhan Dedeoğlu}

Department of Marketing, Ege University, Turkey

\section{Fatima Regany}

Department of Marketing and Distribution Management, University of Lille 2, France

\section{Elif Üstündağli}

Department of Marketing, Ege University, Turkey

\section{Wided Batat}

Department of Tourism Marketing, University of Lyon 2, France

\begin{abstract}
Identifying the 'religion-ethnicity-wellbeing' nexus as an understudied topic in marketing and consumer behavior research, we propose three main trajectories for future research: Firstly, given the politics of religions, there is a need for studying societies that suffer from and are affected by religio-ethnic tensions and also different types of risks that threaten people's wellbeing in such contexts. Secondly, future research should investigate how and why markets may generate and mediate religio-ethnic prejudices and antagonism that put society's wellbeing at risk. Thirdly, with the upsurge of transcultural alternative religiosities/spiritualities, researchers should examine how through the processes of religious hybridization and hybrid consumption people change their existing consumption patterns and how alternative religiosities/spiritualities influence their sense of wellbeing, particularly in contexts where religious shifts are resisted.
\end{abstract}

Keywords: religion, religiosity, ideology, politics, ethnicity, wellbeing, identity, consumption, multi-ethnic/cultural markets, conflicts

\section{Introduction}

A review of marketing and consumer behavior literatures on ethnicity and acculturation reveals two key streams that investigate: (1) the extent to which religiosity influences people's choice of lifestyles and various market offerings (services and products) (e.g., Hirschman, 1981, 1982, 1984; Hirschman and Holbrook, 1982; Tan and James, 1985; Wilkes et al., 1986; Laroche, Kim, and Tomiuk, 1998; Essoo and Dibb, 2004; Hamlett et al., 2008); and (2) whether/how, under various acculturation strategies, people maintain/abandon their religious identities and practices in multi-ethnic/cultural societies and marketplaces (e.g., Bailey and 
Sood, 1993; Gentry et al., 1995; Jamal, 2003a; Jamal and Chapman, 2000; Lindridge, 2005). We acknowledge these studies' valuable contributions to marketing theory at large; yet, as we shall explore in this paper, we believe that the interrelatedness of religiosity and ethnicity offers an extensive scope for new research agendas, especially in pressing areas of enquiry such as 'wellbeing' - a prime topic in Transformative Consumer Research (TCR) (Mick et al., 2011) and social policy (see for example European Policy Centre's 'Wellbeing 2030' statement).

In the context of ethnicity, other disciplines (e.g., sociology, psychology, politics, and religious, cultural and development studies) have already established a rich repository of knowledge on the relevance of religion to different aspects (e.g., physical, psychological, economic, social, cultural, and political) of wellbeing (see for example, Burgess, 1978; Tajfel and Turner, 1986; Blaine and Crocker, 1995; Levin and Markides, 1988; Levin et al., 1996; Levin and Taylor, 1998; Lian and Oneal, 1997; Cairns, and Darby, 1998; Haslam et al., 2008; Ysseldyk et al., 2010). Yet, the 'religion-ethnicity-wellbeing' nexus has remained significantly understudied in marketing and consumer behavior research, even within the TCR and Macromarketing (e.g., see Benton, Jr., 2014) traditions. Addressing this significant gap in our field, we propose three trajectories that can hopefully stimulate new research ideas.

Before discussing these paths, we would like to emphasize two points: Firstly, as stressed by Demangeot et al. (2014, in this issue) and Visconti et al. (2014), studying ethnicity can no longer be confined to the theoretical boundaries of migration and acculturation. Therefore, we conceive religion not just within the scope of national border crossing but more broadly in multi-ethnic/cultural societies and marketplaces, even within 'local contexts' (Ger, 2013; Sandıkçı and Jafari, 2013) where nationality and ethnicity are not necessarily demarcation criteria (Jafari and Süerdem, 2012). Secondly, our focus on religio-ethnic conflicts is mainly due to the more 'critical implications' (Pechmann et al., 2011; Jafari, forthcoming) such issues have on society's wellbeing; therefore, we do not by any means intend to critique religions or deny their various 'positive' aspects (Witter et al., 1985; Ellison, 1991; Nash, 2000; Burroughs and Rindfleisch, 2002; Wallis, 2010).

\section{Trajectory 1: studying the contexts of religio-ethnic conflicts}

In the era of intra and inter civilizational encounters (Zizek, 2002), intra-religious conflicts of Shia-Sunni (e.g., in Iraq, Pakistan, Syria, Saudi Arabia, and Bahrain) and Catholic-Protestant (e.g., in Northern Ireland) camps and inter-religious unrests (e.g., in the Central African Republic, India, Nigeria, Indonesia, Azerbaijan-Armenia, and Cyprus) are all alarming examples that testify to the importance of religion to everyday life scenarios. In the midst of such religio-ethnic tensions, it is not religion per se, but the 'religious' (what represents religions), that comes under fire. Whilst the spirit of religion remains untouched in its celestial shelter, the very material representations (e.g., churches, mosques, synagogues, temples, books, flags, symmetries, and visual images) and belongings (e.g., businesses, automobiles, homes, farms, and goods) of the 'religious' (and of course the un-religious) are ridiculed, insulted, or destroyed on their terrestrial grounds.

The roots of such religious antagonism should be searched for not in religions (as no religion propagates violence) but in the 'religious', as the manifestation of ethno-cultural differences that are often instrumentally stimulated and manipulated by socio-economic and political/ideological motives (see Asad, 2003, and also Ger and Belk, 1996). For example, the current violence between Christians and Moslems in the Central African Republic is all about 
the legitimacy of political power in the country. As such, politically instrumentalized religiosity, stripped of its transcendental values, becomes an autonomous source of legitimizing 'self' and delegitimizing the 'other(s)' (Roy, 2004; Bar-Tal, 1990; Ashouri, 2011). An immediate outcome of such conflicts is therefore nothing but devastation of lives (of both humans and nature), social and communal ties, national integrity, economic resources and opportunities, cultural heritage, and so forth. Such distressing matters have remained considerably overlooked in our discipline. Ethnicity research has treated religion largely as a politically neutral concept and in politically/ideologically (relatively) stable contexts. As Ger (2013, p.498) reminds us, "religion occupies a significant position in modern lives" and understanding the politics of religions offers implications for our collective wellbeing.

Therefore, we suggest that ethnicity research examine the notion of religion through the lens of normative (Lindridge, 2009) and formative (Jafari and Goulding, 2008) political/ideological dynamics that influence people's perception of their religious identities and, ultimately, wellbeing. Instrumentalized religiosity often results in strong ethnocentric behaviors (Blagojević, n/d) and identity myopia (Jafari, 2012) that affect various types of relationships (e.g., social, cultural, psychological, and economic) amongst people with different religious orientations. As Pechmann et al. (2011) tactfully assert, religio-ethnic tensions impose new types of vulnerabilities (e.g., marginalization and stereotypes) on societies around the world. Such conflicts also transgress their contextual boundaries (e.g., community or country) and affect other peoples who share similar religio-ethnic sensibilities and identities in other parts of the world. Hence, researchers should study societies that suffer from and are affected by religio-ethnic tensions; and in doing so, they should explore different types of risks (e.g., physical, psychological, economic, and socio-cultural) that threaten people's (e.g., consumers, businesses, and society at large) wellbeing and investigate how they experience vulnerabilities and what their coping or adaptive strategies are.

\section{Trajectory 2: understanding why/how markets may create new risks of prejudice}

A given practice is the enacted knowledge of a particular entity (such as the social, cultural, and ideological) (Warde, 2005). When enacted, religious orientations (e.g., beliefs and knowledge) become tangible through the procedure of material engagement with everyday life practices and modes of production, promotion, distribution, consumption, and disposition (e.g., of services, goods, signs and symbols) in public spheres. In multi-ethnic/cultural societies religio-ethnic (dis)similarities become more visible as various, and sometimes conflicting, commercial and non-commercial (e.g., religious institutions) markets (see Gauthier and Martikainen, 2013) generate myriad resources such as merchandizing (Hall, 2010) and commodified signs and symbols (Slater, 1997) that feed individuals' varying selfactualization projects, including their practice of religion as 'culture or identity' (Jafari and Süerdem, 2012). To illustrate, Süerdem (2013) explains how opportunistic and profit-oriented market behaviors (e.g., instrumental commoditization of religion and developing religious brands and market segments) can contribute to new forms of identity conflicts (e.g., Moslem vs non-Moslem segregation). Linh and Bouchon (2013) also argue that companies' use of advertising and packaging aimed at targeting a specific religious market segment may offend other groups (both the religious and non-religious).

Enriched and diverse in contents, markets can therefore become potential 'sites of ideological conflict' (Jafari and Goulding, 2013) and breeding grounds for 'stereotypes' (Süerdem, 2013; Sandıkçı and Ger, 2010) and 'prejudices' (Pechmann et al., 2011), especially in multi-ethnic-cultural societies. For example, women's wearing hejab (cover) may be 
stereotypically perceived as a sign of religio-ethnic identity or religious extremism (see Jafari and Goulding, 2008) and receive discriminatory reactions from the environment. Similarly, some religious groups may find certain market contents and practices (e.g., commercial advertisements or other media contents) offensive to their religious beliefs (Jafari, forthcoming) and as a result of 'self-stereotyping' (Burris and Jackson, 2000) may, in the long term, experience ill-being in one way or another (e.g., social exclusion, prejudice, and discrimination).

Given the potential of markets in creating religio-ethnic conflicts and vulnerabilities, different market making actors (e.g., states, producers, retailers, religious institutions, and consumers) may 'legitimize/delegitimize' (Suchman, 1995) certain market forms and norms. For example, as Fischer (2008) demonstrates, the Malaysian state uses the 'Halalisation' discourse as an effective tool to hegemonize Moslem Malays over other ethnic groups (the Chinese and Indians) in order to pre-empt potential ethnic conflicts and discrepancies over claims to political power. Such policies, however, are less likely to resolve risks of prejudice amongst different religio-ethnic groups who may experience feelings of inclusion in or exclusion from market participation, simply because "inclusion and exclusion are essentially about power relationships" (Pechmann et al., 2011, p. 27), and in multi-ethnic/cultural markets, different groups try to gain legitimacy through market participation (Suchman, 1995).

Based on this discussion, future research should investigate how and why markets may generate and mediate religio-ethnic prejudices and conflicts and propose policy implications for enhancing wellbeing for society at large. Researchers should also examine how "marketing tactics [e.g., segmentation] and marketplaces [e.g., their contents and structures] contribute to marginalization and how these can be changed so that all people can participate to their fullest extent, enhancing their dignity" (Pechmann et al., 2011, p. 28). Drawing upon Süerdem's (2013) account, future research should critically examine the political, ideological, and economic motivations behind market making institutions that opportunistically take advantage of people's emotional, pragmatic, and cultural interests in religion and intensify religio-ethnic antagonism. As Hirschman (2013) elaborates, perhaps history can teach us how religio-ethnic conflicts and differences in the market can be minimized in the interest of society's overall wellbeing. Therefore, historical approaches to religio-ethnic research could fructify this area of enquiry.

\section{Trajectory 3: toward understanding alternative religiosities/spiritualities and hybrid consumption}

"The twin forces of neoliberalism and consumerism are penetrating and transforming the 'religious', though in locally-embedded forms" (Gauthier and Martikainen, 2013, p. xv). For example, there has been a shift toward "more experiential rather than creed-based forms of religion", "a move from a regime of orthodoxy towards a regime of orthopraxy" (ibid, p. 4). Other factors such as the rapid growth of communication media, the transformation of traditional religious institutions, and erosion of nation-state boundaries that historically described religion and prescribed religiosity have collectively given rise to a transcultural form of religiosity/spirituality that seeks salvation, not necessarily in the life hereafter but in this very worldly life and now (ibid). As Dawson (2013) also suggests, consumer culture has produced an 'entangled' form of modernity, in which, in the pursuit of wellbeing, individuals engage in non-mainstream and alternative religiosities/spiritualities that are not ideological in nature. Although consumer culture generated alternative religiosities/spiritualities are more 
tangible in western (secular) societies (Gauthier and Martikainen, 2013), with the increase of global mobility and expansion of consumer culture, they are also becoming more evident in traditionally religious societies (Jafari and Süerdem, 2012). The emergence of such alternative religiosities/spiritualities lead to religious hybridization and hybrid forms of consumption, where people transgress the boundaries of traditional religio-ethnic identities to embrace wellbeing in all aspects of everyday life (see Niculescu, 2013, Dawson, 2013).

On the other hand, hybrid consumption can be a direct consequence of transculturalism and interculturalism. As a result of cross-cultural adoption (Sood and Nasu, 1995; Kiong and Kong, 2000) and intercultural learning processes (Ger and Belk, 1996; Jafari and Goulding, 2013), people construct and negotiate hybrid identities and combine both religious and nonreligious consumption patterns (De Groot, 2008; Jafari and Süerdem, 2012). Such hybrid forms of identity and consumption can contribute to the emergence of liquid (Beckford, 1996; Bauman, 1997) and reflexive (Beck, 2010) forms of religiosities, which are not anchored in any specific and rigid religio-ethnic identity framework and are shaped by new religious codes defined in hybrid cultural contexts in a globalized era.

These discussions lead us to the question of change and resistance in people's everyday life engagement with(in) markets. As such, future research should study the role of markets and marketing practices in generating intercultural/transcultural and hybrid religiosities/spiritualities and investigate how these alternative religiosities/spiritualities influence people's sense of wellbeing. It should also investigate how through the process of religious hybridization people improvise, navigate, and transform their existing consumption patterns and identity issues. Last but not least, researchers should examine whether or not shifting religious identities may have 'negative consequences' (Bruce, 2014) for people's wellbeing, particularly in contexts where micro/macro institutional forces (e.g., family, society, state) resist (e.g., issues of conformity/non-conformity) such transformations.

\section{Conclusion}

Research (e.g., Jamal, 2003b; Hirschman, 2013) has already established that markets avail people (regardless of their religio-ethnic differences) with numerous opportunities to peacefully co-exist and enjoy collective welfare. Parallel to this, prior work (e.g., Burroughs and Rindfleisch, 2002; Wallis, 2010; Ger, 2013; Gauthier and Martikainen, 2013) indicates that religion continues to have a significant impact on individuals' general wellbeing in society. Therefore, studying the nexus of 'religion-ethnicity-wellbeing' in the context of markets is highly pertinent to contemporary society. In this vein, the three areas we highlighted above are meant to encourage our fellow scholars to embark on new research journeys, particularly toward better understanding of the role of religion-market nexus in creating wellbeing in multi-ethnic/cultural contexts.

\section{References}

Asad, T. (2003) Formations of the Secular: Christianity, Islam, Modernity (Cultural Memory in the Present). CA: Stanford University Press.

Ashouri, D. (2011) 'Creeping Secularism', Comparative Studies of South Asia, Africa and the Middle East 31(1): 46-52.

Bailey, J.M. and Sood, J. (1993) 'The Effects of Religious Affiliation on Consumer Behavior: A Preliminary Investigation', Journal of Managerial Issues 5(3): 328-352. 
Bar-Tal, D. (1990) 'Causes and Consequences of Delegitimization: Models of Conflict and Ethnocentrism', Journal of Social Issues 46(1): 65-81.

Bauman, Z. (1997) Postmodernity and its Discontents. Cambridge: Polity.

Beck, U. (2010) A God of One's Own: Religion's Capacity for Peace and Potential for Violence. Cambridge: Polity.

Beckford, J. A. (1996) 'Postmodernity, High Modernity and New Modernity: Three Concepts in Search of Religion', in K. Flanagan and P. C. Jupp (eds.) Postmodernity, Sociology and Religion, pp. 30-47. Basingstoke: Macmillan Press.

Benton, Jr., R. (2014) 'Special Issue on Religion and Macromarketing: Journal of Macromarketing, 2016', Journal of Macromarketing 34(2): 232-233.

Blagojević, M. (n/d) 'Revitalization of Religion and Dialogue', in M. Vukomanović and M. Vučinić (eds.) Religious Dialogue in the Balkans: The Drama of Understanding, pp. 217222. Belgrade: Belgrade Open School.

Blaine, B. and Crocker, J. (1995) 'Religiousness, Race, and Psychological Wellbeing: Exploring Social Psychological Mediators', Personality and Social Psychology Bulletin 10(21): 1031-1041

Bruce, S. (2014) 'Authority and Freedom: Economics and Secularization', in J-C. Usunier and J. Stolz (eds.) Religions as Brands: New Perspectives on the Marketization of Religion and Spirituality, pp. 191-204. Surry: Ashgate Publishing Limited.

Burgess, M.E. (1978) 'The resurgence of ethnicity: Myth or reality?' Ethnic and Racial Studies 1(3): 265-285.

Burris, C.T. and Jackson, L.M. (2000) 'Social identity and the true believer: Responses to threatened self-stereotypes among the intrinsically religious', British Journal of Social Psychology 39(2): 257-278

Burroughs, J. and Rindfleisch, A. (2002) 'Materialism and Well-Being: A Conflicting Values Perspective', Journal of Consumer Research 29(3): 348-370.

Cairns, E., and Darby, J. (1998) 'The conflict in Northern Ireland: Causes, consequences, and controls', American Psychologist 53(7): 754-760.

Dawson, A. (2013) 'Entangled Modernity and Commodified Religion: Alternative Spirituality and the 'New Middle Class', in F. Gauthier and T. Martikainen (eds.) Religion in Consumer Society: Brands, Consumer and Markets, pp. 127-142. Surrey: Ashgate Publishing Limited.

De Groot, C.N. (2008) 'Three Types of Liquid Religion’, Implicit Religion 11(3): 277-296.

Demangeot, C., Broeckerhoff, A., Kipnis, E., Pullig, C., and Visconti, L. (2014) 'Consumer well-being among shifting places and ethnicities', Marketing Theory 14(3).

Ellison, C.G. (1991) 'Religious Involvement and Subjective Well-Being', Journal of Health and Social Behavior, 32(1): 80-99.

Essoo, N. and Dibb, S. (2004) 'Religious Influences on Shopping Behaviour: An Exploratory Study', Journal of Marketing Management 20(7-8): 683-712.

European Policy Centre (2013) 'Wellbeing 2030', available at http://www.epc.eu/prog_forum.php?forum_id=8\&prog_id=2, accessed 13 February 2013.

Fischer, J. (2008) Proper Islamic Consumption: Shopping among the Malays in Modern Malaysia. Copenhagen: NIAS Press.

Gauthier, F. and Martikainen, T. (2013) Religion in Consumer Society: Brands, Consumer and Markets. Surrey: Ashgate Publishing Limited.

Gentry, W.J., Jun, S. and Tansuhaj, P. (1995) 'Consumer acculturation processes and cultural conflict: how generalizeable is a North American model for marketing globally?' Journal of Business Research 32(2): 129-39. 
Ger, G. (2013) 'Islamic marketing at the Nexus of global markets-religions-politics and implications for research', Marketing Theory 13(4): 497-503.

Ger, G. and Belk, R.W. (1996) 'I'd like to buy the world a coke: Consumptionscapes of a less affluent world', Journal of Consumer Policy 19(3): 271-304.

Hall, S. (2010) 'Visualising difference: picturing a multi-ethnic street', Researching the spatial and social life of the city 1: 49-65. LSE Working Paper Series, available at: http://eprints.lse.ac.uk/41635/, accessed 12 March 2014.

Hamlett, J., Bailey, A.R., Alexander, A. and Shaw, G. (2008) 'Ethnicity and Consumption: South Asian food shopping patterns in Britain, 1947-75', Journal of Consumer Culture 8(1): 91-116.

Haslam, A., Jetten, J., Postmes, T., and Haslam, C. (2008) 'Social Identity, Health and Wellbeing: An Emerging Agenda for Applied Psychology', Applied Psychology 58(1): 123.

Hirschman, E.C. (1981) 'American Jewish Ethnicity: Its Relationship to Some Selected Aspects of Consumer Behavior', Journal of Marketing 45(3): 102-110.

Hirschman, E.C. (1982) 'Religious Affiliation and Consumption Processes: An Initial Paradigm', in N.J. Sheth (ed.) Research in Marketing (Vol. 6), pp. 131-170. Greenwich, CT: JAI Press.

Hirschman, E.C. (1984) 'Experience seeking: A subjectivist perspective of consumption', Journal of Business Research 12(1): 115-136.

Hirschman, E. (2013) 'Back to the future: Islamic Spain as a model for marketing efflorescence', Marketing Theory 13(4): 513-520.

Hirschman, E.C. and Holbrook, M.B. (1982) 'Hedonic Consumption: Emerging Concepts, Methods and Propositions', Journal of Marketing 46(3): 92-101.

Jafari, A. (2012) 'Islamic Marketing: insights from a critical perspective', Journal of Islamic Marketing 3(1): 22-34.

Jafari, A. (forthcoming) 'Towards an Understanding of Religion-related Vulnerability in Consumer Society', in K. Hamilton, S. Dunnett, and M. Piacentini (Eds.) Vulnerable Consumers: Conditions, contexts and characteristics. London: Routledge.

Jafari, A. and Goulding, C. (2008) "WWe Are Not Terrorists!" UK Based Iranians, Consumption Practices, and the 'Torn Self', Consumption, Markets \& Culture 11(2): 7393.

Jafari, A. and Goulding, C. (2013) 'Globalization, reflexivity and the project of the self: a virtual intercultural learning process', Consumption, Markets \& Culture 16(1): 65-90.

Jafari, A. and Süerdem, A. (2012) 'An Analysis of Material Consumption Culture in the Moslem World', Marketing Theory 12(1): 59-77.

Jamal, A. (2003a) 'Marketing in a multicultural world: The interplay of marketing, ethnicity and consumption', European Journal of Marketing 37(11/12): 1599-1620.

Jamal, A. (2003b) 'Retailing in a multicultural world: the interplay of retailing, ethnic identity and consumption', Journal of Retailing and Consumer Services 10(1): 1-11.

Jamal, A. and Chapman, M. (2000) 'Acculturation and Inter-Ethnic Consumer Perceptions: Can You Feel What We Feel?' Journal of Marketing Management 16(4): 365-391.

Kiong, T.C. and Kong, L. (2000) 'Religion and Modernity: Ritual Transformations and the Reconstruction of Space and Time', Social and Cultural Geography 1(1): 29-44.

Laroche, M., Kim, C. and Tomiuk, M.A. (1998) 'Italian ethnic identity and its relative impact on the consumption of convenience and traditional foods', Journal of Consumer Marketing 15(2): 125-151. 
Levin, J.S. and Markides, K.S. (1988) 'Religious Attendance and Psychological Wellbeing in Middle-Aged and Older Mexican Americans’, Sociology of Religion 49(1): 66-72.

Levin, J.S., Markides, K.S., and Ray, L.A. (1996) 'Religious Attendance and Psychological Wellbeing in Mexican Americans: A Panel Analysis of Three-Generations Data', The Gerontologist 36(4): 454-463.

Levin, J.S. and Taylor, R.J. (1998) 'Panel Analyses of Religious Involvement and Wellbeing in African Americans: Contemporaneous vs. Longitudinal Effects', Journal for the Scientific Study of Religion 37(4): 695-709.

Lian, B. and Oneal, J.R. (1997) 'Cultural Diversity and Economic Development: A Cross-National Study of 98 Countries, 1960-1985', Economic Development and Cultural Change 46(1): 61-77.

Lindridge, A. (2005) 'Religiosity and the construction of a cultural-consumption identity', Journal of Consumer Marketing 22(3): 142-151.

Lindridge, A. (2009) 'Acculturation, Religion and Consumption in Normative Political Ideology', Advances in Consumer Research 36(1): 16-17.

Linh, H.H. and Bouchon, F. (2013) 'The Relationship between Food Constraints and Destination Choice of Malaysian Muslim Travellers', Asia-Pacific Journal of Innovation in Hospitality and Tourism 2(1): 69-86.

Mick, D.G., Pettigrew, S., Pechmann, C., and Ozanne, J.L. (eds.) (2011) Transformative Consumer Research for Personal and Collective Wellbeing. New York: Routledge.

Nash, J.A. (2000) 'Towards the revival and reform of the subversive virtue: frugality', in A.R. Chapman, R.L. Petersen, and B. Smith-Moran (eds.) Consumption, Population and Sustainability: Perspectives from Science and Religion, pp. 167-190. Washington, DC: Island Press.

Niculescu, M. (2013) 'Find Your Inner God and Breathe: Buddhism, Pop Culture, and Contemporary Metamorphosis in American Judaism', in F. Gauthier and T. Martikainen (eds.) Religion in Consumer Society: Brands, Consumer and Markets, pp. 91-108. Surrey: Ashgate Publishing Limited.

Pechmann, C., Moore, E.S., Andreasen, A.R., Connell, P.M., Freeman, D., Gardner, M.P., Heisley, D., Lefebvre, R.C., Pirouz, D.M., and Soster, R.L. (2011) 'Navigating the Central Tensions in Research on At-Risk Consumers: Challenges and Opportunities', Journal of Public Policy \& Marketing, 30(1): 23-30.

Roy, O. (2004) Globalized Islam. New York, NY: Columbia University Press.

Sandıkçı, Ö. and Ger, G. (2010) 'Veiling in Style: How Does a Stigmatized Practice Become Fashionable?', Journal of Consumer Research, 37(1): 15-36.

Sandıkçı, Ö. and Jafari, A. (2013) 'Islamic Encounters in Consumption and Marketing', Marketing Theory 13(4): 411-420.

Slater, D. (1997) Consumer Culture and Modernity. Cambridge: Polity Press.

Sood, J. and Nasu, Y. (1995) 'Religiosity and Nationality: An Exploratory Study of Their Effect on Consumer Behavior in Japan and the United States', Journal of Business Research 34(1): 1-9.

Suchman, M. (1995) 'Managing Legitimacy: Strategic and Institutional Approaches', The Academy of Management Review 20(3): 571-610.

Süerdem, A. (2013) 'Yes my name is Ahmet, but please don't target me. Islamic marketing: Marketing Islam TM?', Marketing Theory 13(4): 285-295.

Tajfel, H. and Turner, J.C. (1986) 'The social identity theory of intergroup behavior', in S. Worchel and W.G. Austin (eds.) Psychology of intergroup relations, pp. 7-24. Chicago: Nelson-Hall. 
Tan, C.T. and James, M. (1985) 'Relating Ethnic Attitudes and Consumption Values in an Asian Context', Advances in Consumer Research 12(1): 122-125.

Visconti LM, Jafari A, Batat W, Broeckerhoff A, Dedeoglu AÖ, Demangeot C, Kipnis E, Lindridge A, Peñaloza LN, Pullig C, Regany F, Ustundagli E and Weinberger MF (2014) Consumer ethnicity three decades after: A TCR agenda. Working paper, Paris.

Wallis, J. (2010) Rediscovering Values: On Wall Street, Main Street, and Your Street: A Moral Compass for the New Economy. New York: Howard Books.

Warde, A. (2005) 'Consumption and theories of practice', Journal of Consumer Culture 5(2): 131-53.

Wilkes, R.E., Burnett, J.J., and Howell, R.D. (1986) 'On the meaning and measurement of religiosity in consumer research', Journal of the Academy of Marketing Science 14(1): 4756.

Witter, R.A., Stock, W.A., Okun, M.A., and Haring, M.J. (1985) 'Religion and Subjective Well-Being in Adulthood: A Quantitative Synthesis', Review of Religious Research, 26(4): 332-342.

Ysseldyk, R., Matheson, K., and Anisman, H. (2010) 'Religiosity as Identity: Toward an Understanding of Religion From a Social Identity Perspective', Personality and Social Psychology Review 14(1): 60-71.

Zizek, S. (2002) Welcome to the Desert of the Real. London: Verso Books. 